\title{
Perception- Attention - Memory Reaction Time of PE Teacher and Computer Teacher Candidates
}

\author{
Elif Karagün \\ Correspondence: Elif Karagün, Assoc. Prof. Dr. Kocaeli University, Faculty of Sport Sciences, Department of Recreation, \\ Turkey.
}

Received: October 6, 2018

doi:10.11114/jets.v6i11a.3805
Accepted: October 10, $2018 \quad$ Online Published: November 29, 2018

URL: https://doi.org/10.11114/jets.v6i11a.3805

\begin{abstract}
The purpose of the study is to determine the visual and auditory reaction time, perception, attention and memory levels of PE teacher candidates and computer teacher candidates.

For this purpose, after giving necessary information to the teacher candidates of the Department of Physical Education and Sports and the candidates of Computer Teaching Department of Kocaeli University, 88 voluntary students, were applied Benton Perception, Attention-Memory test and Newtest 1000 which determined their visual and auditory reaction time. Data was analyzed by using SPSS 21.00 software. The Man Whitney U test was used for the comparison of the paired groups since the data in the normality analysis did not follow a normal distribution. As a result, it was found that computer teacher candidates had higher levels of attention-perception and memory scores than those of PE teacher candidates. PE teacher candidates were found to be faster to perceive auditory stimulus and give reactions.
\end{abstract}

Keywords: visual perception, memory, reaction time, pe and sports teacher, computer teacher

\section{Introduction}

It was stated in many studies done in this area that the information that comes to the thalamus is sent to the necessary parts of the brain by tracing two ways that are called stream of feeling and stream of thought. It was also stated that stream of feelings is fast and specific for every individual; stream of thought, however, is much slower and it works according to cognitive skills. Feelings were defined as the sudden reactions to the stimulus, and thoughts were defined as regular reactions that take time to develop (Duman, 2007; Martínez-Miranda, Aldea, 2005). We are frequently coming across the concept "meta-cognition" in many scientific studies regarding Education. Attention-Perception and Memory significantly were mentioned in this concept and it was mentioned that this is an internal state in cognitive process (Akpunar, 2011; Bacanl1, 2003). Attention in the phrase Metacognition, which comes from the Latin word "concentrare", means focusing on a condition or an object. Attention directs several cognitive sources, it works as a filter for many stimulus and do selections to deal with natural information flow, and it shows the appropriate reaction to the stimulus and it helps memory and other executive functions in healthy functioning by working together with sensory and motor systems (Balota, Faust, 2001).

Ettric (1998), states that attention skills have a great importance in every phase of school years; therefore it is really necessary to give importance to improve attention skills beginning at pre-school times. He believes that educational problems that might arise in the following years could be reduced in this way (quoted from: Kaymak, 2003). It is said that attention is based on perception as the ability to select and edit from different materials in terms of environment. Perception, however, is defined as the state of being aware of objects, relationships, and events via sense organs; it is the state of recognising the situations; it is the ability of putting an object or a phenomenon in one place; and the ability of understanding it as a whole. For example, perceiving a scent is the sensation; and the distinction of what that scent is the perception. It is also said that perception is necessary for the individual to give appropriate reactions, too (Sürücü, Kula, 2016; Köknel, Özuğurlu, Aytar Bahadır 1993). Reaction pace is important when the individual gives reaction. This situation is particularly found significant in many studies that deal with performance. It is stated in those studies that reaction pace consists of reaction time and action time. And reaction time in this combination is defined as the period between when the stimulus is received and when the individual intentionally starts to give reaction to that stimulus (Ganong, 2001 ). Reaction time is also said to have two types: auditory and visual and this reaction time is not only affected by perception and attention; but it is also affected by their impetus level. It is stated that the recipient who 
receives the data, the transmitter which gives out the data and the effector which reacts to the data are necessary organs to get the perception (Köknel, Özuğurlu, Aytar Bahadır, 1993). In reaction time process, the individual's dominant hands are used for the organ that gives the reaction; sound for the auditory and light for the auditory stimulant are used for the stimulus. There are studies saying that students have difficulty in concentrating and maintaining this concentration at schools at the rate $30 \%$. They particularly fail to take responsibilities such as homework inside the classroom (Quoted from: Sürücü, Kula, 2016). It is stated that a student who had problems in taking responsibilities, in maintaining his concentration confessed that he got easily bored during the classes and he started to think that he wouldn't be able to tasks related to school work. Therefore, attention is necessary to develop in educational platforms because it has a great importance on motivation, participation and learning. It was explained that attention both selects and filters the stimuli and helps to choose the appropriate behaviour; it works together with both sensorial and motor systems; So it sets a precondition for the memory and other executive functions to work properly (Balota, Faust, 2001; Sürücü, Kula, 2016).

Teaching profession requires being skilled at leadership by giving appropriate reactions as well as being a role model for the learner and transferring the information to the learner. Attention is accepted to be important for the learner to learn effectively, to adapt the school environment and to have good communication. Therefore, it is also important to deal with necessary issues such as perception in learning and to solve problems that might arise in these issues. The most important routers at schools are teachers for the solution of problems such as perception attention and motivation. Educationalists are considered as not only teachers but also trainers, so their emotional and cognitive features are also considered as important.

It was observed in this study that teachers' emotional features were mostly examined in other studies in the literature. Teacher candidates' perception, attention and memory levels were measured as well as their auditory and visual reaction pace because teachers and trainers making decisions inside the classroom, solving the problems, directing students, evaluating and giving reactions need to be examined cognitively, as well. Cognitive aspects of perception-attention-memory and visual and auditory reaction times of the teacher candidates who are going to give computing training and PE classes that are particularly liked by the learner are inquired. In the light of this concept, perception-attention-memory and reaction times of the teacher candidates of computing training and PE classes were searched.

The following sub-problems were looked for answers: 'Is there a difference between the perception-attention-memory and reaction times of the teacher candidates of computing training and PE classes according to their departments?' 'Is there a difference between the perception-attention-memory and reaction times of the teacher candidates of computing training and PE classes according to their gender?'

\section{Method}

In this study, an example of a descriptive study, the universe consists of the final graders of Physical Education and Sports Teaching Department and Computer Teaching Department at Kocaeli University in the academic year of 2014. The sample of the study consists of volunteering students after they were explained the purpose of the study. Before starting the application, necessary permission was taken from the University management and after that the students were informed about the study.

Data Collecting ToolsThe F form, prepared by Benton (1974) and consisting of cards with 15 geometrical designs that measure visual attention-perception-memory functions, was used in order to determine the perception, attention and memory levels of teacher candidates who voluntarily participated in the study. In Benton test, higher scores show that their perception-attention-memory is good. Visual and auditory reaction time measurements were carried out using the Newtest 100. In reaction time measurements, both visual and auditory reaction times are measured in terms of seconds and spilt-seconds. At the end of the tests, higher numeric results mean that their reaction time pace is lower, in other words slower. On the contrary, if the numbers get lower, their reaction time pace is faster (Benton, 1982).

\section{Data Analysis}

Data was analyzed by using SPSS 21.00 software. The Man Whitney U test was used for the comparison of the paired groups since the data in the normality analysis did not follow a normal distribution. And the age variable was analyzed by using Kruskal Wallis. The perception-attention and memory levels and visual and auditory reaction time levels of totally 88 teacher candidates - $44 \mathrm{PE}$ teacher candidates and 44 computer teacher candidates were compared.

\section{Findings}

As seen in Table 1, $39 \%$ of 88 participants are females and 60,2\% are males. In terms of age; $9,1 \%$ of the participants are the age of 19 and $20 ; 50 \%$ of them are at the age of 21 and $22 ; 31,8 \% \%$ of them are at the age of 23and 24 ; and $9,1 \%$ of them are at the age of 25 and over. 
As for their departments; $50 \%$ of the participants study at PE teaching department and the other half study computer teaching. We can also understand from the table that $93,2 \%$ of the students use their right hands dominantly and only $6,8 \%$ of them prefer to use their left hands dominantly.

Table 1. The Frequency Distrubion of the Teacher Candidates in This Study

\begin{tabular}{llll}
\hline & \multicolumn{1}{c}{ Variables } & N & \% \\
\hline Gender & Female & 35 & 39,8 \\
& Male & 53 & 60,2 \\
& Aged 19-20 & 8 & 9,1 \\
& Aged 21-22 & 44 & 50,0 \\
& Aged 23-24 yaş & 28 & 31,8 \\
Department & Aged 25 and over & 8 & 9,1 \\
& Computer teaching. & 44 & 50 \\
Dominant & PE teaching & 44 & 50 \\
hand & Right & 82 & 93,2 \\
& Left & 6 & 6,8 \\
\hline
\end{tabular}

When Benton perception-attention-memory test results were evaluated (Table 2), it was observed that 8 students (18.2) out of 44 computer teacher candidates had higher scores and 20 students $(45.5 \%)$ had acceptable scores. As for the PE teacher candidates, it was seen that only 3 students (6.8\%) had high scores with 14- 15 range of points; 15 of them (34.1\%) had acceptable scores between the ranges of 12-13 points. Again, in computing department, those who got medium scores are 9 students $(20.5 \%)$; those who got substandard scores are 6 students (13.6\%); it was also found that one student (2.3\%) had the limit score, 9. PE candidates scores were found as the following: 10 students (\%22.7) had 11 points, which means medium. 9 people (20.5\%) got 10 points, substandard; 5 people $(11.4 \%)$ were at the limit score by getting 9 points and two students $(4.5 \%)$ got 8 meaning unacceptable level of perception, attention and memory.

Table 2. The perception-attention-memory test results of the teacher candidates

\begin{tabular}{cccc}
\hline Department & Benton Test Scores & N & \% \\
\hline \multirow{3}{*}{ Computing } & $14-15$ high & 8 & 18.2 \\
& $12-13$ acceptable & 20 & 45.5 \\
& 11 medium & 9 & 20.5 \\
& 10 substandard & 6 & 13.6 \\
& 9 limit & 1 & 2.3 \\
PE & $14-15$ high & 3 & 6.8 \\
& $12-13$ acceptable & 15 & 34.1 \\
& 11 medium & 10 & 22.7 \\
& 10 substandard & 9 & 20.5 \\
& 9 limit & 5 & 11.4 \\
& 8 unacceptable & 2 & 4.5 \\
\hline
\end{tabular}

Table 3 gives the scores of the computer and PE teacher candidates from the measurements, and the averages of their perception-attention-memory scores and visual and auditory reaction times, their standard deviations, and maximum and minimum values. When Table 3 was examined, it is observed that Benton test averages of computer teaching students' perception-attention-memory is 12,1 and minimum score is 9 , which means 'high'. Yet, this is 11,02 for PE teaching students and the minimum average score for them is 6 , meaning 'low'. And the difference between the scores of these two departments was found significant. $(\mathbf{p}=, \mathbf{0 0 5} ; \mathbf{p}<\mathbf{0 , 0 5})$. The visual reaction times of computer teacher candidates were found at a bit lower pace when compared to PE teacher candidates. However, this difference between two departments was found insignificant when the analysis was done in terms of both right hand ( $\mathrm{p}=, 796 ; \mathrm{p}>0,05)$, and left hand. ( $p=, 225 ; \mathrm{p}>0,05)$. When the evaluation was done in terms of auditory reaction pace, the auditory reaction times of computer teacher candidates were calculated as (.2037) for the right hand and (.1881) for the left hand. This 
result for the PE teacher candidates was found as (.1803) for the right hand and (.1682) for the left hand. It was found at a lower pace according to their average scores. The values of these two departments were found statistically significant for both right hand $(\mathbf{p}=, \mathbf{0 , 0 1 7} ; \mathbf{p}<\mathbf{0 , 0 5})$, and for left hand $(\mathrm{p}=, 046 ; \mathrm{p}<0,05)$ at the end of the analysis.

Table 3. The comparison of perception-attention-memory and visual and auditory reaction times of the teacher candidates according to their departments

\begin{tabular}{|c|c|c|c|c|c|c|c|c|c|c|c|c|}
\hline \multirow{2}{*}{$\begin{array}{l}\text { Applied } \\
\text { Scales }\end{array}$} & \multicolumn{5}{|c|}{ Computer teacher candidates } & \multicolumn{5}{|c|}{ PE teacher candidates } & \multicolumn{2}{|c|}{ Total } \\
\hline & $\begin{array}{l}\text { Mean } \\
\text { Rank }\end{array}$ & $\begin{array}{l}\text { Sum of } \\
\text { Ranks }\end{array}$ & $\begin{array}{l}\text { Ave. } \\
\text { score }\end{array}$ & Mi & Mx & $\begin{array}{l}\text { Mean } \\
\text { Rank }\end{array}$ & $\begin{array}{l}\text { Sum of } \\
\text { Ranks }\end{array}$ & $\begin{array}{l}\text { Ort } \\
\text { Pua }\end{array}$ & Mi & Max & $\begin{array}{c}\mathrm{U} \\
\text { scores }\end{array}$ & $\begin{array}{c}P \\
\text { value }\end{array}$ \\
\hline Benton & 52,08 & 2291,5 & 12,1 & 9 & 15 & 36,92 & 1624,5 & 11.02 & 6 & 15 & 634,5 & ,005 \\
\hline $\begin{array}{l}\text { Visual react. } \\
\text { Right hand }\end{array}$ & 43,80 & 1927 & ,2050 & .14 & .32 & 45,20 & 1989 & .1990 & .14 & .26 & 937 & ,796 \\
\hline $\begin{array}{l}\text { Visual react. } \\
\text { Left hand }\end{array}$ & 47,60 & 2094,5 & , 1957 & .14 & .32 & 41,40 & 1821,5 & .1843 & .11 & .26 & 831,5 &, 225 \\
\hline $\begin{array}{l}\text { Auditory } \\
\text { React. Right } \\
\text { hand }\end{array}$ & 51,02 & 2245 & .2037 & .12 & .34 & 37,98 & 1671 & .1803 & .12 & .26 & 681 &, $\mathbf{0 , 0 1 7}$ \\
\hline $\begin{array}{l}\text { Audi.React. } \\
\text { Left hand }\end{array}$ & 44,94 & 2197,5 & .1881 & .11 & .33 & 39,06 & 1718,5 & .1682 & .12 & .29 & 728,5 & ,046 \\
\hline
\end{tabular}

When the total number of participants of the teacher candidates was evaluated in terms of gender, no significant difference was found in terms of Benton perception-attention -memory and auditory and visual reaction times (Table 4).

Table 4. The comparison of perception-attention-memory and visual and auditory reaction times of the teacher candidates according to their gender

\begin{tabular}{|c|c|c|c|c|c|c|c|c|c|c|c|c|}
\hline $\begin{array}{l}\text { Applied } \\
\text { Scales }\end{array}$ & $\begin{array}{l}\text { Female } \\
\text { Mean } \\
\text { Rank }\end{array}$ & $\begin{array}{l}\text { Sum of } \\
\text { Ranks }\end{array}$ & $\begin{array}{l}\text { Ave. } \\
\text { score }\end{array}$ & Mi & $\mathbf{M x}$ & $\begin{array}{l}\text { Male } \\
\text { Mean } \\
\text { Rank }\end{array}$ & $\begin{array}{l}\text { Sum of } \\
\text { Ranks }\end{array}$ & $\begin{array}{l}\text { average } \\
\text { point }\end{array}$ & Mi & $\mathbf{M x}$ & $\begin{array}{c}\text { Total } \\
\text { U } \\
\text { score }\end{array}$ & $\mathbf{P}$ \\
\hline Benton & 40.11 & 1404 & 11.3 & 6 & 15 & 47.40 & 2512 & 11.74 & 8 & 15 & 774 & .184 \\
\hline $\begin{array}{l}\text { Visual react. } \\
\text { Right hand }\end{array}$ & 48.54 & 1699 & .2089 & 14 & 32 & 41.83 & 2217 & .1974 & 14 & 31 & 786 & .228 \\
\hline $\begin{array}{l}\text { Visual react } \\
\text { Left hand }\end{array}$ & 45.71 & 1600 & .1928 & 11 & .30 & 43.70 & 2316 & .1882 & 13 & 32 & 885 & .717 \\
\hline $\begin{array}{l}\text { Audio react } \\
\text { Right hand }\end{array}$ & 46.57 & 1630 & .1958 & 12 & 28 & 43.13 & 2286 & .1895 & 12 & 34 & 855 & .536 \\
\hline $\begin{array}{l}\text { Audio react } \\
\text { Left hand }\end{array}$ & 45.01 & 1575 & .1797 & 11 & 29 & 44.16 & 2340.5 & .1771 & 11 & 33 & 909.5 & .878 \\
\hline
\end{tabular}

\section{Results, Conclusions and Recommendations}

When we compare the perception-attention-memory and visual and auditory reaction times of final grade students at computer teaching department and PE teaching department, the rate of accurate answers to Benton test of computer teacher candidates was found significantly higher than PE teacher candidates. It was concluded from these results that the perception-attention-memory levels of computer teacher candidates were higher than PE teacher candidates. Benton test averages of computer department students were found as "good" with the score of 12.1 whereas it was found as 11.02 for the students at PE teaching department.

No other studies were found in the Literature to be carried out with the aim of making comparison between the visual perception-attention-memory of students at computer teaching department and PE teaching department, even in other departments. Even though there weren't any studies done to measure the attention levels of teacher candidates when scanning the Literature, it was seen that other studies had done measurements by using Benton test for labour-labourer health, geriatric diseases, hyperactivity problems and neurological issues (Benton, 2006; Didycz, Nitecka, Bik-Multanowski, 2017; Dougherty, Mathias, Marsh, Greve, Bjork, Moeller, 2003; Kasai, Ishizaki, Ishii, Yamaguchi, Yamadori, Meguro, 2009; Önen, İşseven, Sabuncu, Çakmak, Tan, 1999).

In some measurements in which Benton test was used, it was emphasised that getting education had a positive effect on test scores (Kasai, Ishizaki, Ishii, Yamaguchi, Yamadori, Meguro, 2009; Seo, Lee, Choo, Youn, Kim, Jhoo, Suh, Paek, 
Jun, Woo, 2007). In our study, too, when computer teaching students and PE teaching students were compared, Benton perception-attention-memory scores were found to be higher in favor of computer teaching. The reason for this can be explained that teacher candidates studying at computer teaching have a more theoretical - based education and they have done more studies academically before getting into the university exam. It was also predicted that it could be because computing department inherently requires sitting down in front of a screen and using more visual attention. These results of ours were proved to match with other findings in the Literature. Even though Benton tests results show differences according to age (Kasai, Ishizaki, Ishii, Yamaguchi, Yamadori, Meguro, 2009), no difference was found in terms of age in our study. When the findings were compared in terms of gender, either, no significant difference was found between female and male students. It was seen that these findings also matched with the findings in the Literature (Kasai, Ishizaki, Ishii, Yamaguchi, Yamadori, Meguro, 2009). When the visual reaction times were compared with visual perception and visual stimuli, it was found that reaction times of computer teacher candidates were slower at right and left hands than PE teacher candidates. However, when these results were analysed, the difference was found insignificant. It was determined that computer teacher candidates got positive scores when they needed to do visual perception or visual distinction, and especially when they needed to do cognitive tasks based on remembering. On the contrary, PE teacher candidates' scores got better, yet not very significantly, when there was a task not based on memory or distinction, a task that requires somatic reactions. When we look at the other studies done on this subject, it was observed that there is a significant difference between the left hand reaction times against the light in favor of tennis players in terms of visual reaction time; it was also found that the values of the reaction time against the light of those who do exercise to the light were better than the sedentary; that special balance training had a positive contribution to the improvement of reaction time performances and body mass index values (Çankaya, Gökmen, Çon Taşmektepligil, 2014; Polat 2000; Sucan, Yılmaz, Can, Süer, 2005). In addition, the reaction time values against the light of people who do exercise were stated to be better than the sedentary (Arslanoğlu, Aydoğmuş, Arslanoğlu, Şenel, 2010).

When we look at the studies done on this issue, there are studies showing that PE teacher candidates were faster than computer teacher candidates in terms of auditory reaction time; and the results of measurements were found to be significantly higher in favor of PE teacher candidates in terms of both right and left hand. Although there were not found any studies comparing teacher candidate groups, it was mentioned that concentration and special balance trainings have a strong impact on reaction time measurements (Çolakoğlu, Tiryaki, Moral,1993; Orhan, 2001; Polat, 2000). Studies in the Literature illustrate that there is a remarkable relation between balance and reaction time. They also show that reaction time of sportsmen gets quite short due to their balance. They state that the reaction time of professional sports people is higher (Arslanoğlu, Aydoğmuş, Arslanoğlu, Şenel, 2010; Davranche, Burle, Audiffren, Hasbroucq, 2006; Erkmen, Suveren, Göktepe, Yazıcıoglu, 2007; Perrin, Schneider, Deviterne, Perrot, Constantinescu, 1998; Vuillerme, Nougier, 2004).

It was determined that when people were re-tested particularly in dynamic balance tests had a faster reaction time than sedentary students (Hansen, Dieckmann, Jensen, Jakobsen, 2000; Nakamoto, Mori. 2008). In the light of this information it can be said that because PE teacher candidates get practical lessons and classes based on exercise and because these classes include speed and balance and they strengthen both the speed and the balance, it was considered that auditory reaction time of $\mathrm{PE}$ teacher candidates is usually higher than computer teacher candidates.

When this study and the findings found in the Literature were taken into consideration, it can be suggested that activities including balance training based on exercise and attention in physical education classes should be increased so that the perception-attention- memory and reaction time of these students can be improved both for their academic success and for their social life. In addition, studies to improve visual perception-attention and memory could be done by using computer environment as there is a great demand for computers and technological changes in today's world. Teachers who will deliver these classes can be informed. Besides, perception-attention and memory activities integrated with exercise could be increased for the teachers to comprehend some problems and work coordinative.

\section{References}

Akpunar, B. (2011). Biliş ve üstbiliş (metabiliş) kavramlarının zihin felsefesi açısından analizi. Turkish studies international periodical for the languages, Literature and History of Turkish or Turkic, 6(4), 353-365.

Arslanoğlu, E., Aydoğmuş, M., \& Arslanoğlu, Ş. Ö. (2010). Badmintoncularda reaksiyon zamanı ve denge ilişkisi. Niğde Üniversitesi Beden Eğitimi ve Spor Bilimleri Dergisi, 4(2), 131-136.

Bacanlı, H. (2003).Gelişim ve Öğrenme. Ankara: Nobel Yayın Dağıtım.

Balota, D. A., \& Faust, M. (2001). Attention in dementia of the alzheimer's type. Handbook Of Neuropsychology, 6, 51-80.

Benton, L. A. (1982). L'application clinique du test de retantion visuelle. Du entre de psychologie appliquee 15, Rue 
Henri-Heine-Paris.

Benton, L. A. (2006). Benton Visual Retention Test. https://medical-dictionary.thefreedictionary.com/Benton+Visual+Retention+Test.

Çankaya, S., Gökmen, B., Çon, M., \& Taşmektepligil, M., Y. (2014). Denge geliştirici özel antrenman uygulamalarının 11 yaş genç erkeklerin reaksiyon zamanları ve vücut kitle indeksi üzerine etkisi. Spor ve Performans Araştırmaları Dergisi, 5(12), 59-63. https://doi.org/10.17155/spd.07723

Çolakoglu, M., Tiryaki, Ş., \& Moralı, S. (1993). Konsantrasyon çalışmalarının reaksiyon zamanı üzerine etkisi, Spor Bilinıleri Dergisi, 4(4), 32-47.

Davranche, K., Burle, B., Audiffren, M., \& Hasbroucq, T. (2006). Physical exercise facilitates motor processes in simple reaction time performance: an electromyographic analysis. Neuroscience Letters, 396(1), 54-56. https://doi.org/10.1016/j.neulet.2005.11.008

Didycz, B., Nitecka, M., \& Bik-Multanowski, M. (2017). The Use of d2 and Benton Tests for Assessment of Attention Deficits and Visual Memory in Teenagers with Phenylketonuria. JIMD Reports, 40, $23-29$. https://doi.org/10.1007/8904_2017_60

Dougherty, D.M., Mathias, C. W., Marsh, D. M., Greve, K. W., Bjork, J. M., \& Moeller, F. G. (2003). Commission error rates on a continuous performance test are related to deficits measured by the Benton Visual Retention Test. Assessment, 10(1), 3-12. https://doi.org/10.1177/1073191102250526

Duman, B. (2007). Neden beyin temelli öğrenme? Ankara: Pegem A Yayıncılık.

Erkmen, N., Suveren, S., Göktepe, A. S., \& Yazıcıoglu, K. (2007). Farklı branşlardaki sporcuların egzersiz sonrası denge performanslarının karşılaştırılması. SPORMETRE Beden Eğitimi ve Spor Bilimleri Dergisi, V(3), $115-122$. https://doi.org/10.1501/Sporm_0000000080

Ganong, W. F. (2001). Review of Medical Physiology. San Francisco: McGraw -Hill.

Hansen, M. S., Dieckmann, B., Jensen, K., \& Jakobsen, B. W. (2000). The Reliability of balance tests performed on the kinesthetic ability trainer (Kat 2000). Knee Surg, Sports Traumatol, Arthrosc, 8(3), 180-185. https://doi.org/10.1007/s001670050211

Kasai, M., Ishizaki, J., Ishii, H., Yamaguchi, S., Yamadori, A., \& Meguro, K. (2009). Normative data on Benton visual form discrimination test for older adults and impaired scores in clinical dementia rating 0.5 participants: community-based study. The Osaki-Tajiri Project, Psychiatry and Clinical Neurosciences, 63(1), 9-16. https://doi.org/10.1111/j.1440-1819.2008.01901.x

Kaymak, S. (2003). Dikkat Toplama Ĕ̆itimi Programının Illköğretim 2. ve 3. Sinıf Öğrencilerinin Dikkat Toplama Becerilerinin Geliştirilmesine Etkisi. Yayınlanmamış doktora tezi. Ankara Üniversitesi. Sosyal Bilimler Enstitüsü. Ankara.

Köknel, Ö., Özuğurlu, K., \& Aytar, B. G. (1993). Davranış Bilimleri (Ruh Bilim). İstanbul: Yaylım Matbaası.

Martínez-Miranda, J., \& Aldea, A. (2005). Emotions in human and artificial intelligence. Computers in Human Behavior, 21(2), 323-341. https://doi.org/10.1016/j.chb.2004.02.010

Nakamoto, H., \& Mori, S. (2008). Sport-specific decision-making in a go/no go reaction task: difference among nonathletes and baseball and basketball players. Perceptual and Motor Skills, 106(1), 163-171. https://doi.org/10.2466/pms.106.1.163-170

Önen, L., İşsever, H., Sabuncu, H., Çakmak, D., \& Tan, O. (1999). Gemi inşa iş kolunda çalışanlarda dikkat ve kaygının değerlendirilmesi. Düşünen Adam, 12(1), 28-31.

Orhan, S. (2001). Aktif sporcu ve sedanter ögrencilerin reaksiyon zamanı, dikey sıçrama ve anaerobik güç değerlerinin karşılaştırılması. Gazi Üniversitesi, Sağlık Bilimleri Enstitüsü, Beden Eğitimi ve Spor Anabilim Dalı, Yüksek Lisans Tezi, Ankara.

Perrin, P., Schneider, D., Deviterne, D., Perrot, C., \& Constantinescu, L. (1998). Training 1mproves the adaptation to changing visual conditions in maintaining human posture control in a test of sinusoidal oscillation of the support. Neuroscience Letters, 245(3), 155-158. https://doi.org/10.1016/S0304-3940(98)00208-0

Polat, Y. (2000). Çabuk kuvvet ve sprint antrenmanlarının reaksiyon zamanına etkisi. Selçuk Üniversitesi, Sağlık Bilimleri Enstitüsü, Beden Eğitimi Ve Spor Anabilim Dalı, Yüksek Lisans Tezi, Konya,

Seo, E. H., Lee, D. Y., Choo, I. H., Youn, J. C., Kim, K. W., Jhoo, J. H., ... Woo, J. L. (2007). Performance on the Benton visual retention test in an educationally diverse elderly population, Journal of Gerontology: Psychological 
Sclences, 62 (3), 191-193.

Sucan, S., Yılmaz, A., Can, Y., \& Süer, C. (2005). Aktif futbol oyuncularının çeşitli denge parametrelerinin değerlendirilmesi. Sağlık Bilimleri Dergisi (Journal Of Health Sciences), 14(1), 36-42.

Sürücü, A., \& Kula, E. (2016). Dikkat becerisinin geliştirilmesi, eğitim ve psikolojiden yansımalar. İstanbul: Çizgi Kitabevi. 115-125.

Vuillerme, N., \& Nougier, V. (2004). Attentional demand for regulating postural sway: the effect of expertise in gymnastics, Brain Research Bulletin, 63(2),161-165. https://doi.org/10.1016/j.brainresbull.2004.02.006

\section{Copyrights}

Copyright for this article is retained by the author(s), with first publication rights granted to the journal.

This is an open-access article distributed under the terms and conditions of the Creative Commons Attribution license which permits unrestricted use, distribution, and reproduction in any medium, provided the original work is properly cited. 